\title{
Do neighbouring countries encourage the demand of international business tourism?
}

DOI 10.1515/ejthr-2016-0018

received 20 November, 2015; accepted 5 May, 2016

Abstract: This paper aims at determining the factors that influence the growth of international business tourism and understanding whether the demand growth of business tourism spreads across neighbouring countries. For the development of the empirical research, data has been collected from a sample of 136 countries worldwide, and spatial econometric techniques have been used. Evidence that supports the idea that the main factors related to the increase in incomes of business tourism are the private investment on tourism assets, the leisure tourism and the trade openness in relation to the outside world is presented. This study also reveals that the demand of business tourism in a country is not contagious, that is, the demand varies neither with the demand of its neighbours nor with their exogenous characteristics. The results have important implications for the choice of tourism policy goals at national levels and the corresponding policy instruments.

Keywords: Planning policy; Economic growth; Contagion effects; Business tourism; Convention tourism.

\section{Introduction}

Over recent years, applied researchers have become increasingly interested in international business tourism. This fact may be explained because business tourism is both an important and a booming sector. According to the World Travel and Tourism Council ${ }^{1}$ (WTTC), in 2014,

\footnotetext{
*Corresponding author: Pedro Carvalho, School of Technology and Management, Polytechnic Institute of Viana do Castelo, Portugal, E-mail: pc@estg.ipvc.pt

Miguel A. Márquez, Montserrat Díaz, Faculty of Economics and Business Administration, University of Extremadura, Spain
}

the revenue from travel and business tourism worldwide totalled U.S. \$ 1,175.67 billion and represented, in the same year, about $31 \%$ of the revenues resulting from travel and leisure tourism. On the other hand, according to this organisation, international business tourism is a booming sector that revealed, in the past decade, an average annual growth exceeding $10 \%$.

This tourism sector has important implications at the national level as well. Several researchers have highlighted that business tourism grants countries a multitude of benefits of an economic, social and cultural nature; namely, it reduces the problem of seasonality associated with leisure tourism, shares the same physical infrastructures of leisure tourism, improves the image of the destination, stimulates the leisure market, is a more powerful source of revenue than leisure tourism, strengthens international trade and cultural ties between countries and is a tourism sector strongly generator of direct and indirect jobs (Wootton \& Stevens, 1995; Bradley, Hall \& Harrison, 2002; Crouch \& Louviere, 2004; Guizzardi, 2005; HavenTang, Jones \& Webb, 2007; Bernini, 2009).

The majority of studies in this field have focused on the analysis of this sector using micro data (primary data obtained from surveys) and a consumer behaviour approach. However, a few studies have used a macro approach, examining the factors that may lead to the enhancement of competitiveness of the countries in this tourism segment (Var, Cesario \& Mauser, 1985; Kulendran \& Witt, 2003) and none of them has considered that international business tourism operates in a global context. Thus, each of these previous studies has researched only a part of this complex phenomenon. As they are almost always focused on the micro and consumer approach and limited to a country or a region, they do not consider the aggregated (national) results of this sector. Therefore, government policies for the development of this sector do not benefit from the complementary perspective that an aggregate analysis may provide.

Additionally, it is important to highlight the existence of an increasing field of knowledge carried out by several researchers (Deng \& Athanasopoulos, 2011; Zhang, Xu \& Zhuang, 2011; Marrocu \& Paci, 2011, 2013; De la Mata \& 
Llano, 2013; Paci \& Marrocu, 2014), who demonstrate the influence of neighbouring regions in the performance of a tourist destination. However, no studies that allow presenting evidence about the role of neighbouring countries in business tourism can be found.

Consequently, the purpose of this research is twofold. First, it seeks to study the (macro) factors that may be controlled by the action of economic agents and political decision-makers and that determine the growth of business tourism on a global scale. Second, as the main contribution of this paper, it intends to understand whether the demand of business tourism is contagious and spreads across neighbouring countries. To this end, we follow the theoretical framework put forward by Manski (2000), and a cross section of 136 economies is used. This paper has the following layout: first, the theoretical framework is presented. Second, the empirical method is analysed. This is followed by empirical results. Finally, some concluding remarks are brought out.

\section{Literature review}

\subsection{The controllable determinants of business tourism}

The determinants of the demand for a tourist destination result not only from factors closely associated with demand, but also from factors connected with supply (Middleton, Fyall, Morgan \& Ranchhod, 2009). This means that the concepts related to tourism are linked to the demand side and, as such, are inconsistent with accepted standards and definitions in other industries (Smith, 1988). Therefore, it is pertinent to carry out a reflection about the concepts related to tourism supply.

According to several researchers (Smith, 1988; Page, 2003; Pike, 2008; Middleton et al., 2009), it is possible to understand that tourism is linked to the travel and tourism industry and brings together a multiplicity of interveners that contribute to the notion of value presented to the tourist consumer. Indeed, the constituent elements of the tourism supply chain that meet the needs of visitors are numerous (Kaukal, Höpken \& Werthner, 2000; Flagestad \& Hope, 2001; Tapper \& Font, 2004; Zhang, Song \& Huang, 2009; Hong \& Yan, 2011). Consequently, the existence of more or less demand will depend on the configuration of these elements in a tourist product. Thus, the tourism product should be envisaged as a combination of various elements that constitute the tourist offer (Davidson \& Maitland, 1997; Middleton et al., 2009).

However, how does scientific community conceptualise a tourist destination? A tourist destination may be understood as a place competing at a global scale, whose competitiveness is determined by several factors (Crouch \& Ritchie, 1999; Dwyer, Forsyth \& Rao, 2000; Enright \& Newton, 2004, 2005). For example, Crouch and Ritchie (1999) explain the relevance of the competitive (micro) environment, global (macro) environment, core resources and attractors, supporting factors, qualifying determinants (namely, location, cost, dependencies and safety) and destination management for the competitiveness of a tourist destination. Other authors also posit that a tourist destination may be seen as a geographic area where there is a cluster of resources responsible for the creation of tourist experiences that tourists seek and, at the same time, motivate them to move into that space (Murphy, Pritchard \& Smith, 2000; Pike, 2008; Cooper, Fletcher, Fyall, Gilbert \& Wanhill, 2008).

Although literature on tourism has analysed the range of factors that may influence tourism demand, namely, by highlighting factors strictly related to demand and factors associated with supply (Crouch \& Ritchie, 1999; Dwyer et al., 2000; Eilat \& Einav, 2004; Enright \& Newton, 2004; 2005; Muñoz \& Martin, 2007; Mill, 2010; Seetaram, 2012), the scientific community has, additionally, focused on factors that justify the displacement of people and organisations for business purposes.

Studies of the scientific community in the business tourism field are, above all, divided into two specific areas: (i) determinants associated with the participation of individual delegates at a convention, which may be typified in personal and business factors, factors related to the association and conference and factors related to the country of destination (Oppermann \& Chon, 1997; Lee \& Park, 2002; Zhang, Leung \& Qu 2007; Severt, Wang, Chen \& Breiter, 2007; Judith \& Thompson, 2009; Shin, 2009; Yoo \& Zhao, 2010; Draper et al., 2011; Sox et al., 2013, Fenich, Scott-Halsell, Ogbeide \& Hashimoto, 2014; Whitfield, Dioko, Webber \& Zhang, 2014); and (ii) determinants associated with the choice of location by companies and associations to carry out a convention, which may be classified into factors related to the country of origin and factors related to the country of destination (Var et al., 1985; Oppermann, 1996; Crouch \& Ritchie, 1998; Bradley et al., 2002; Kulendran \& Witt, 2003; Crouch \& Louviere, 2004; Hankinson, 2005; Chen, 2006; Haven-Tang et al., 2007; DiPietro, Breitner, Rompf \& Godlewska, 2008; Dragičević, Jovičević, Belšić, Stankov \& Bošković, 2012; Park, Wu, Shen, Morrison \& Kong, 2014). 
Considering the factors related to the choice of location by companies and associations to carry out a convention, it is possible to understand that there are some factors that may be controlled by the action of economic agents and political decision-makers and, at the same time, that there is a variety of factors that, for reasons that are natural, historical or alien to their own destiny, are beyond the capacity of being influenced by the various actors (i.e. climate, natural disasters, natural landscape, popular culture, geographic location, distance from attendants, historic buildings and monuments, amongst others). Therefore, it should be emphasised that there are factors, which are controllable by institutional actors, that may influence the business tourism at the tourist destination, namely, (i) the monetary vacation cost in the destination country (the monetary expense of transportation and access, the cost of suitable accommodation and the cost of the meeting space); (ii) the equipment for business meetings (the availability and ability of the site to provide suitable-sized facilities and service quality); (iii) security (the place provides a safe political environment, a secure social environment and a weak possibility of strikes, boycotts and other possible adverse events); (iv) the dynamism of leisure tourism, industry, trade and services; (v) the infrastructure (the suitability and standard of the local infrastructure); (vi) the ability of urban, commercial and economic regeneration; (vii) hospitality (associated with qualification and preparation for tourism on the part of residents); (viii) the accessibility of the site (in particular, the connections to the business destination and the infrastructure for transport); (ix) the room equipment (the number of available rooms and the perception of the service standards); (x) the opportunities for culture and recreation (museums, monuments, parks, local tours, historical sites, theatres, bars, restaurants, nightclubs, sports and activities that the tourist may engage in, either as spectator or participant); and (xi) the degree of financial and trade opening of the country of tourist destination in relation to the outside world (influencing the trading relationship between countries, namely, negotiations, business deals and selling, amongst others).

\subsection{The influence of neighbouring tourist destinations}

Over the past century, many social scientists have argued that agents belonging to the same group tend to behave similarly and their behaviours vary positively with the prevalence of this behaviour in the group (Hyman, 1942; Merton, 1957; Granovetter, 1979, as cited in Manski, 2000). More recently, econometric and experimental analysis has also sought to understand well-defined forms of social interactions (McElroy, 1990; Rosenzweig \& Wolpin, 1994; Flinn \& Del Boca, 1995, as cited in Manski, 2000) and empirical research has distinguished, from amongst these studies, three hypotheses, according to Manski (2000, p. 127): ](1) endogenous interactions, wherein the propensity of an agent to behave in some way varies with the behaviour of the group; (2) contextual interactions, wherein the propensity of an agent to behave in some way varies with exogenous characteristics of the group members; (3) correlated effects, wherein agents in the same group tend to behave similarly because they have similar individual characteristics or face similar institutional environments'. Thus, according to Manski (2000), individuals might be influenced by their social environments, through endogenous or contextual interactions, whilst non-social phenomena might be explained by correlated effects.

Over the past decade, literature on tourism has also revealed some interest about spatial interactions between tourist destinations. For example, some authors have explained that a tourist destination may be seen as a territory, whose boundaries are not clearly defined (Pike, 2008; Cooper et al., 2008), that depends not only on the stakeholders present on the tourist destination but also on the stakeholders present on the other destinations (Pavlovich, 2003; Ermen, Gnoth \& Harris, 2006; Cooper et al., 2008). It is worth noting that, in line with these researchers, Deng and Athanasopoulos (2011), Zhang et al. (2011), Marrocu and Paci (2011, 2013), De la Mata and Llano (2013) and Paci and Marrocu (2014) explain that tourist regions may present patterns of spatial dependence and demonstrate the influence of neighbouring tourist regions in the performance of a tourist destination, namely, on tourism demand. However, no studies can be found yet on the influence of neighbouring countries in business tourism context.

The above reflections lead, thus, to the development of the following research questions: (1) Which are the factors influencing the growth in the demand of international business tourism that may be susceptible to be controlled by economic agents and policy makers of destinations? (2) Do neighbouring countries stimulate the demand growth of international business tourism in a country? 


\section{Method}

\subsection{Sample}

With the aim of conducting an analysis in the short- and medium-term perspective, data were collected from all countries worldwide and provided by the WTTC, Data World Bank and Worldwide Governance Indicators (integrated into the World Bank), for the last five years of the past decade, specifically for the years 2005 and 2009. In order to proceed with sample homogenisation, countries that had missing values in the reference years are excluded from the sample. Indeed, a sample collection composed of data from 136 countries was designed (representing the main destinations for business tourism in the global context). To make the modelling and estimation, the GeoDA (Anselin, 2003) software was used after the construction of the data table in Microsoft Office 2010 Excel software.

\subsection{Dependent and Explanatory Variables}

According to the research questions, we considered, as dependent variable, the variable 'business travel and tourism spending'. This variable can be obtained from the WTTC through the database available online. ${ }^{1}$ According to the WTTC (2011), 'business travel and tourism spending' consists of business trips spending made within a country by residents and international visitors. However, it is noteworthy that data for this variable are subject to the incorporation of the gross domestic product (GDP) deflator of the corresponding countries (from the base year 2002). ${ }^{2}$ Following the existing literature and the controlled factors by several stakeholders that influence business tourism, different explanatory variables are introduced into the analysis. Thus, we present the explanatory variables considered:

- The capital investment variable will operationalise the opportunities for entertainment and culture resulting from private investment, investment in accommodation and meeting facilities and connections of private companies to the destination/location of the meeting (related to the accessibility dimension). ${ }^{3}$ However, it is worth noting that the data will be subject to the incorporation of the GDP deflator for the respective countries, in order to obtain a time series with real data (base year 2002);
- the leisure travel and tourism spending variable explains the dynamism of leisure tourism and can be measured on the basis of the spending on travel and leisure tourism adjusted by the GDP deflator (base year 2002);

- for the vacation cost in the country of destination, the cost of living variable is proposed, which will be handled from the proxy ratio - conversion factor of purchasing power parities to the market exchange rates. This ratio is the result obtained by dividing the conversion factor of purchasing power parities by the market exchange rate;

- the economic activity (GDP) variable aims at operationalising the dynamism of public and private sectors (in particular, industry, trade and services) of the economic activity and generating added value for the tourist. This variable will be measured on the basis of the real GDP indicator built from the GDP at constant prices (base year 2002);

- the degree of economy openness in relation to the outside world will be operationalised with the trade openness variable and foreign direct investment variable. The first variable can be measured on the basis of imports plus exports from the country of destination in relation to the GDP of the country of destination (see Kulendran \& Witt, 2003; Lloyd \& MacLaren, 2002; Aizenman \& Noy, 2006); the second variable will be tested as the inflow of net investment by foreign investors in relation to GDP, in line with the work developed by Aizenman and Noy (2006) and Azman-Saini et al. (2010).

Regarding the governance factors present in the literature, we propose

- the government effectiveness variable, which will operationalise the factor related to the opportunities for entertainment and culture resulting from public investment, hospitality associated with the qualification of the residents and general infrastructure, promoting aspects of the visitor's accessibility;

- the political stability and rule of law variables for safety policy and social security factors, respectively;

- the regulatory quality variable, which will operationalise the ability of economic, commercial and urban regeneration of the countries promoted by public authorities.

The relationship between the explanatory variables and the controllable factors is presented briefly in Table 1 . 
Table 1: The relationship between the explanatory variables and the controllable factors

\begin{tabular}{|c|c|}
\hline $\begin{array}{l}\text { Explanatory } \\
\text { variables }\end{array}$ & Controllable factors \\
\hline Living costs & - Vacation cost \\
\hline Capital investment & $\begin{array}{l}\text { - Opportunities for entertainment and culture } \\
\text { resulting from private investment; } \\
\text { - Accommodation facilities; } \\
\text { - Meeting facilities; } \\
\text { - Connections of private companies to } \\
\text { the destination/location of the meeting } \\
\text { (accessibility). }\end{array}$ \\
\hline Political stability & - Safety policy \\
\hline Rule of law & - Social security \\
\hline GDP & $\begin{array}{l}\text { Dynamism of public and private sectors of } \\
\text { the economic activity (industry, trade and } \\
\text { services) }\end{array}$ \\
\hline Regulatory quality & $\begin{array}{l}\text { The ability of economic, commercial and } \\
\text { urban regeneration of the countries }\end{array}$ \\
\hline $\begin{array}{l}\text { Government } \\
\text { effectiveness }\end{array}$ & $\begin{array}{l}\text { - Opportunities for entertainment and culture } \\
\text { resulting from public investment; } \\
\text { - Hospitality associated with the qualification } \\
\text { of the residents; } \\
\text { - General infrastructure (namely, visitor's } \\
\text { accessibility) }\end{array}$ \\
\hline $\begin{array}{l}\text { Leisure travel and } \\
\text { tourism spending }\end{array}$ & - Dynamism of leisure tourism \\
\hline $\begin{array}{l}\text { Foreign direct } \\
\text { investment }\end{array}$ & $\begin{array}{l}\text { Degree of financial openness in relation to } \\
\text { the outside world }\end{array}$ \\
\hline Trade openness & $\begin{array}{l}\text { - Degree of trade openness in relation to the } \\
\text { outside world }\end{array}$ \\
\hline
\end{tabular}

Source: Own elaboration

\subsection{Data Sources of the Explanatory Variables}

Taking the explanatory variables exposed into account, we present the sources of data collection considered: two explanatory variables, namely capital investment and leisure travel and tourism spending, based on the WTTC through the database available online. ${ }^{4}$ Cost of living (proxy ratio of purchasing power parities to market exchange rate), economic activity (GDP), trade openness (imports plus exports in relation to the GDP) and foreign direct investment are variables that can be obtained from the Data World Bank. ${ }^{5}$

Finally, the governance variables for government effectiveness, political stability, absence of violence and regulatory quality stem from the Governance Indicators are provided by the World Bank. ${ }^{6}$ Towards a better understanding, we summarise the units of measurement associated with the dependent and explanatory variables in Table 2.

\subsection{Spatial Data Analysis}

This article aims at determining the controllable factors that influence the growth rate of international business tourism and understanding whether the demand of business tourism is contagious. To address these objectives, we follow the conceptual framework proposed by Manski (2000). Thus, our empirical research distinguishes the existence of three hypotheses: (1) correlated effects, wherein countries in the same neighbourhood tend to show similar levels of growth of business travel and tourism spending because they share similar national characteristics or face similar institutional environments; (2) endogenous interactions, wherein the growth of business travel and tourism spending in a country varies with the growth of business travel and tourism spending of its neighbourhood; and (3) contextual interactions, wherein the growth of business travel and tourism spending in a country varies with exogenous characteristics of its neighbourhood.

Representing the growth of business travel and tourism spending in country $i$ by $\triangle B T T S_{i}$, the following cross-sectional specification is used:

$\Delta$ BTTS $_{i}=\alpha+\beta \Delta \mathrm{Xi}+\varepsilon \mathrm{i}$

where $\alpha$ and $\beta$ are the parameters to be estimated, $x_{i}$ is the set of variables conditioning the growth of business travel and tourism spending in each country $i$ and $\varepsilon_{i}$ is the $(N \times 1)$ vector of independent and identically distributed error terms with variance. Specification (1) only considers the existence of correlated effects, that is, the interdependence amongst neighbouring countries is not contemplated.

If endogenous interactions occur, the equation would contain a spatial lag of the growth of business travel and tourism spending variable amongst the explanatory variables: the growth of business travel and tourism spending corresponding to each country depends on a weighted 
Table 2: Units of measurement associated with the variables

\begin{tabular}{|c|c|c|}
\hline Variables & Units of measurement & Data sources \\
\hline $\begin{array}{l}\text { Business travel and tourism } \\
\text { spending }\end{array}$ & $\frac{U S \$ \text { bn }(B T T S)}{\text { GDP Deflator }}$, , where $\quad G D P$ Def. $=\frac{G D P \text { current US\$ }}{\text { GDP constant } 2002 \text { US } \$}$ & $\begin{array}{l}\text { World Travel and Tourism Council } \\
\text { (and Data World Bank) }\end{array}$ \\
\hline Living costs & $\frac{\text { Purchasing Power Parity }}{\text { Market Exchange Rate }}$ & Data World Bank \\
\hline Capital investment & $\frac{\text { USS bn (Cap.Inv.) }}{\text { GDP Deflator }}$, where $G D P$ Def. $=\frac{\text { GDP current USS }}{\text { GDP constant } 2002 \text { US\$ }}$ & $\begin{array}{l}\text { World Travel and Tourism Council } \\
\text { (and Data World Bank) }\end{array}$ \\
\hline Political stability & $\begin{array}{l}\text { The indicator is measured in units ranging from about }-2.5 \text { to } 2.5 \text {, } \\
\text { with higher values corresponding to better outcomes }\end{array}$ & $\begin{array}{l}\text { Worldwide Governance Indicators } \\
\text { provided by the World Bank }\end{array}$ \\
\hline Rule of law & $\begin{array}{l}\text { The indicator is measured in units ranging from about }-2.5 \text { to } 2.5 \text {, } \\
\text { with higher values corresponding to better outcomes }\end{array}$ & $\begin{array}{l}\text { Worldwide Governance Indicators } \\
\text { provided by the World Bank }\end{array}$ \\
\hline GDP & GDP 2002 constant US\$ & Data World Bank \\
\hline Regulatory quality & $\begin{array}{l}\text { The indicator is measured in units ranging from about }-2.5 \text { to } 2.5 \text {, } \\
\text { with higher values corresponding to better outcomes }\end{array}$ & $\begin{array}{l}\text { Worldwide Governance Indicators } \\
\text { provided by the World Bank }\end{array}$ \\
\hline Government effectiveness & $\begin{array}{l}\text { The indicator is measured in units ranging from about }-2.5 \text { to } 2.5 \text {, } \\
\text { with higher values corresponding to better outcomes }\end{array}$ & $\begin{array}{l}\text { Worldwide Governance Indicators } \\
\text { provided by the World Bank }\end{array}$ \\
\hline Leisure travel and tourism spending & $\frac{\text { US\$bn }(\text { LTTS })}{\text { GDP Deflator }}$, , where $\quad$ GDP Def. $=\frac{\text { GDP current US\$ }}{\text { GDP constant } 2002 \text { US\$ }}$ & $\begin{array}{l}\text { World Travel and Tourism Council } \\
\text { (and Data World Bank) }\end{array}$ \\
\hline Foreign direct investment & $F D I=\% G D P$ & Data World Bank \\
\hline Trade openness & $\frac{\text { Imports }+ \text { Exports }}{G D P}$ & Data World Bank \\
\hline
\end{tabular}

Source: Own elaboration

average of growth of business travel and tourism spending for neighbouring countries. Therefore, the model to be estimated could be expressed as

$$
\Delta B T T S_{i}=\alpha+\rho \mathrm{W} \Delta \text { BTTS }_{i}+\beta \Delta X_{i}+\varepsilon_{i}
$$

where $\rho$ is the spatial lag parameter and $W$ is the spatial lag matrix.

The last possibility would be to consider that the error term in the equation is spatially auto-correlated. In this situation, the existence of contextual interactions is identified. Hence, any influence omitted from the model specified and spatially auto-correlated will lead to a spatial pattern in the growth of business travel and tourism spending known as 'spatial error dependence'. Thus, the model could be written as

$\Delta B T T S_{i}=\alpha+\beta \Delta X_{i}+\varepsilon_{i ;} \varepsilon_{i=} \lambda W \varepsilon_{i+} \mu_{i}$

where $\lambda$ is a parameter and $u_{i}$ is a disturbance term.

Finally, if the simultaneous existence of endogenous interactions, contextual interactions and correlated effects occurs, the model would be

$$
\Delta \text { BTTS }_{i}=\alpha+\rho \mathrm{W} \Delta \mathrm{BTTS}_{\mathrm{i}}+\beta \Delta \mathrm{X}_{\mathrm{i}}+\varepsilon_{\mathrm{i}} ; \varepsilon_{\mathrm{i}}=\lambda \mathrm{W} \varepsilon_{\mathrm{i}}+\mu_{\mathrm{i}}
$$

The proposed approach will allow us to analyse the relevance of growth of business travel and tourism spending in neighbouring countries on the growth of business travel and tourism spending in a country. To test the three hypotheses derived from the conceptual framework proposed by Manski (2000), we have to accomplish the Moran's I analysis for residuals of the regression and Lagrange multiplier tests (Anselin, 2005):

- Moran's I analysis for residuals of the regression: the Moran's I is defined as $I=\frac{N}{s_{0}} \frac{e^{\prime} w e}{e^{\prime} e}, \quad$ where $e$ is a vector of ordinary least squares residuals, $N$ is the number of countries and $S_{0}=\sum_{i} \sum_{j} w_{i j}$, is the sum of all elements of the matrix of spatial weights. Formally, $w_{i j}=1$ if countries $i$ and $j$ are neighbours and $w_{i j}=0$ otherwise. This (Queen Contiguity) Matrix ensures that interactions between countries with common borders are taken into account. A row-standardised form of the $W$ matrix is used for the ease of economic interpretation. The null hypothesis of Moran's I allows 
us to check the non-existence of spatial autocorrelation;

- Lagrange multiplier (LM) tests: the LM test allow us to verify the null hypothesis of no spatial autocorrelation associated with the residuals of the regression $\left(\mathrm{LM}_{\text {error }}\right)$ as well as verify the null hypothesis of no spatial autocorrelation associated with the spatial lag regression $\left(\mathrm{LM}_{\mathrm{lag}}\right)$. Thus, in the case of LM tests verifying the null hypothesis, we must consider the ordinary least-squares (OLS) regression results; otherwise, the spatial error model (if $\mathrm{LM}_{\text {error }}$ is significant) or the spatial lag model (if $\mathrm{LM}_{\mathrm{lag}}$ is significant) must be estimated.

\section{Results}

The spatial data analysis is estimated for our sample by means of OLS, disregarding interdependence across countries. In this step, we will attempt to find out the existence of interdependence across countries within the estimated relationship.

Table 3 displays that the overall regression is significant $(F=7.905391, p<0.001)$. On the other hand, it also allows verifying that capital investment is significant $(t=$ 4.670757, $p<0.001$ ) and corroborates previous empirical works on the importance of the quality and availability of equipment for accommodation, equipment for catering and similar, entertainment and culture and accessibility (Crouch \& Ritchie, 1998; Bradley et al., 2002; Hankinson, 2005). As expected, leisure travel and tourism spending is individually determinant $(t=2.139127, p<0.05)$ and confirms the looming of several researchers (Davidson \& Maitland, 1997; Kulendran \& Witt, 2003; Hankinson, 2005; Kellerman, 2010), because the countries benefit from the formation of a positive image created by leisure tourism. Finally, we find that the degree of trade openness in relation to the outside world is also significant $(t=3.986831, p$ $<0.001)$. Indeed, the more the economy is exposed to the outside world, the larger is the flow of travel and business travellers, in line with the work developed by Kulendran and Witt (2003).

We still do not find evidence on the existence of heteroskedasticity (White, Breusch-Pagan and KoenkerBassett tests) from this estimation. The value of Moran's $I$ for the residual is 0.1445705 for a Queen Contiguity Matrix and the null hypothesis of no spatial correlation is not rejected $(p>0.05)$. There is, hence, evidence of the non-existence of spatial autocorrelation. In the same line, the LM (lag) test and the LM (error) test are not significant.
Table 3: Regression: ordinary least squares estimation

Dependent variable: business travel and tourism spending

\begin{tabular}{|c|c|c|c|}
\hline Variable & Coefficient & t-statistic & Prob. \\
\hline Constant & 0.0319318 & 0.864913 & 0.3887422 \\
\hline Living costs & 0.2257027 & 1.25494 & 0.2118419 \\
\hline Capital investment & 0.1483015 & 4.670757 & 0.0000076 \\
\hline Political stability & 0.0021101 & 0.639760 & 0.5234998 \\
\hline Rule of law & -0.0157832 & -0.740554 & 0.4603534 \\
\hline GDP & 0.1300636 & 0.785829 & 0.4334538 \\
\hline Regulatory quality & -0.0325241 & -1.453283 & 0.1486511 \\
\hline $\begin{array}{l}\text { Government } \\
\text { effectiveness }\end{array}$ & 0.0221027 & 1.078826 & 0.2827432 \\
\hline $\begin{array}{l}\text { Leisure travel and } \\
\text { tourism spending } \\
\text { Foreign direct }\end{array}$ & 0.1297068 & 2.139127 & 0.0343697 \\
\hline investment & -0.0076308 & -1.332858 & 0.1850028 \\
\hline Trade openness & 0.6887227 & 3.986831 & 0.0001132 \\
\hline
\end{tabular}

Number of observations: 136

$R^{2}$ : 0.387417; Adjusted $R^{2}$ : 0.338410; F-statistic: 7.90539 ( $p$-value: $0.000)$

White test: 49.39911 ( $p$-value: 0.924562)

Breusch-Pagan test: 9.429715 ( $p$-value: 0.4918643 )

Koenker-Bassett test: 5.812303 ( $p$-value: 0.8307784)

Diagnostics for Spatial Dependence for Weight Matrix: Queen Contiguity Matrix

Moran's I [error] test: 0.1445705 ( $p$-value: 0.8850500$)$

Lagrange multiplier [lag] test: 0.1610246 ( $p$-value: 0.6882150$)$

Dependence robust LM [lag] test: 0.8807318 ( $p$-value: 0.3480013$)$

Lagrange multiplier [error] test: 0.0010073 ( $p$-value: 0.974681$)$

Robust LM [error] test: 0.7207145 (p-value: 0.3959096$)$

Source: Own elaboration

Thus, support is not found for the adoption of a spatial lag model or a spatial error model. As we can verify, correlated effects are found, but there is no evidence of endogenous or contextual interactions. Therefore, we can assert that the growth of business travel and tourism spending in a country neither depends on the growth of business travel and tourism spending of its neighbours nor varies with contextual (exogenous) characteristics of these countries. Furthermore, countries in the same neighbourhood tend to show similar levels of growth of business travel 
and tourism spending because they share similar national characteristics or face similar institutional environments (Manski, 2000). Thus, the neighbouring countries have not relevance to the growth of business travel and tourism spending in a specific country, and it is worth noting that these results do not corroborate other studies that demonstrate the influence of neighbouring regions in the performance of a tourist destination (Deng \& Athanasopoulos, 2011; Zhang et al., 2011; Marrocu \& Paci, 2011, 2013; De la Mata \& Llano, 2013; Paci \& Marrocu, 2014).

\section{Concluding remarks}

This study was motivated by the increasing relevance of business tourism in the world economy. In recent years, literature has presented the micro-determinants associated with the participation of individual delegates at a convention and associated with the choice of location by companies and associations. However, research on the competitiveness of business tourism, as well as an increasing field of knowledge in tourism studies, namely, the influence of neighbouring in the performance of a tourist destination, has been neglected by the scientific community. On the other hand, academic scholars have been focused on the micro and consumer approach, ignoring an aggregated (national) approach. Nevertheless, there is the lack of a complementary perspective that an aggregate analysis may provide to policy-makers and economic agents. Thus, the development of this paper aims at determining the (macro) factors that influence the growth of international business tourism and understanding whether the demand growth of business tourism spreads across neighbouring countries.

With respect to the determinants of differences in the growth of business travel and tourism spending amongst countries, the results from this research suggest that differences are explained by economic variables, such as capital investment, leisure travel and tourism spending and trade openness. These macro variables should be considered by policy-makers and economic agents to foster the growth of business tourism in their tourism destination and gain market share in a global context.

Thereby, so as to increase the incomes of business tourism in the short and medium terms, it is important to promote private investment in accommodation facilities, catering, cultural and sporting equipment and transport equipment specifically for touristic purposes, leisure tourism and the degree of trade openness of the country in relation to the outside world.
This information is important for destination marketing organisations and companies in the tourism industry, as well as for policy-makers. Thus, for destination marketing organisations to contribute to the development of a policy of growth in the short and medium terms for travel and business tourism, they must develop strategies to promote business tourism integrated with leisure tourism, for example, assuming the same markets as well as the same promotion and distribution channels.

Companies in the tourism industry should also direct their promotion, in an integrated way, towards the two segments referred to, as well as focus their investments in equipment that creates value throughout the tourism supply chain, in particular in transport (e.g. buses, taxis and rent-a-car), equipment for accommodation and catering (e.g. hotels and restaurants) and equipment for entertainment and culture (e.g. pubs, discos, shops, sporting equipment, amusement and thematic parks, guide tours, theatres and museums).

The political decision-makers, in particular the national and local government, should develop policies that encourage private investment in fixed capital in the tourism industry, for example, creating support programmes for investment and licensing in the tourism industry. On the other hand, they should develop policies to assist the export of goods and services in national companies, thereby stimulating the increase in commercial activity between countries. This could be done, for example, through the implementation of programmes for the modernisation, expansion and qualification of companies, as well as through the development of promotion programmes of domestic products to existing and new markets.

On the other hand, and as the main novelty of this paper, our analysis focuses on the relevance of the level of growth of business travel and tourism spending in one country's neighbours (once previous studies have not addressed the contagion effects of business tourism). In this study, these possible contagion effects have been tested, and our empirical research considered three hypotheses: (i) correlated effects (wherein countries in the same neighbourhood show similar levels of growth of business travel and tourism spending, because they share similar individual characteristics or face similar institutional environments), (ii) endogenous interactions (wherein the growth of business travel and tourism spending in a country varies with the growth of business travel and tourism spending of its neighbourhood) and (iii) contextual interactions (wherein the growth of business travel and tourism spending in a country varies with exogenous features of its neighbourhood). Results demonstrate that 
the growth of business travel and tourism spending in a country does not vary with the behaviour of its neighbour countries or with their exogenous characteristics. Thus, the growth of business travel and tourism spending is not contagious, that is, similar individual characteristics or similar institutional environments explain such similar levels in neighbouring countries. This finding is particularly important to the economic agents and decision-makers of a business destination, once they do not have to take the geographic aspects of neighbourhood into consideration to expand the incomes of business tourism in the short- and medium-term strategy. Furthermore, it should be highlighted that although several countries spend resources to develop tourism cooperation amongst neighbouring countries (namely, the European Travel Commission, ASEAN tourism cooperation and OIC tourism cooperation, amongst others), in the specific case of international business tourism, what we assert is that it is not necessary to try to spend money on this cooperation, that is, it is not necessary to coordinate policies between neighbouring countries to promote international business tourism. The focus should be on national policies.

\section{Notes}

1. Database available online at http://www.wttc.org/ research/economic-data-search-tool/.

2. The GDP deflator was provided by the Data Word Bank from the series of Economic Policy and External Debt, available at http://data.worldbank.org/indicator/all.

3. As we can see at http://www.wttc.org/research/economic-data-search-tool/, the capital investment variable includes capital investment spending by all sectors directly involved in the travel and tourism industry. This also constitutes investment spending by other industries on specific tourism assets, such as new visitor accommodation and passenger transport equipment, as well as restaurants and leisure facilities for specific tourism use.

4. Database available online at http://www.wttc.org/ research/economic-data-search-tool/.

5. Provided by Data World Bank, available at http:// data.worldbank.org/indicator/all.

6. These governance indicators, elaborated by Kaufmann, Kraay and Mastruzzi (2008), can be found at http://info.worldbank.org/governance/wgi.

\section{References}

[1] Aizenman J., \& Noy, I. (2006). FDI and trade - Two-way linkages?. The Quarterly Review of Economics and Finance, 46, 317-337

[2] Anselin, L. (2003). GeoDa 0.9 user's guide. Spatial Analysis Laboratory (SAL), University of Ilinois, Urbana-Champaign, IL

[3] Anselin, L. (2005). Exploring Spatial Data with GeoDa: A Workbook. Spatial Analysis Laboratory (SAL), University of Ilinois, Urbana-Champaign, IL

[4] Azman-Saini, W.N.W., Baharumshah, A. Z., \& Law, S. H. (2010). Foreign direct investment, economic freedom and economic growth: International evidence. Economic Modelling, 27, 1079-1089

[5] Bernini, C. (2009). Convention industry and destination clusters: Evidence from Italy. Tourism Management, 30(6), 878-889

[6] Bradley, A., Hall, T., \& Harrison, M. (2002). Selling cities: Promoting new images for meetings tourism. Cities, 19(1), 61-70

[7] Chen, C.-F. (2006). Applying the analytical hierarchy process (AHP) approach to convention site selection. Journal of Travel Research, 45(2), 167-174

[8] Cliff, A. D., \& Ord, J. K. (1981). Spatial process: Models and applications. London: Pion

[9] Cooper, C., Fletcher, J., Fyall, A., Gilbert, D., \& Wanhill, S. (2008). Tourism - Principles and Practice (4th ed.). Essex: Pearson Education Limited

[10] Crouch, G. \& Louviere, J. (2004) Convention site selection: determinants of destination choice in the Australian domestic conventions sector. Australia: CRC for Sustainable Tourism Pty Ltd

[11] Crouch, G., \& Ritchie, J. R. B. (1998). Convention site selection research: A review, conceptual model and propositional framework. Journal of Convention and Exhibition Management, 1, 49-69

[12] Crouch, G., \& Ritchie, J. R. B. (1999). Tourism, competitiveness and societal prosperity. Journal of Business Research, 44, 137-152

[13] Davidson, R., \& Maitland, R. (1997). Tourism destinations. London: Hodder \& Stoughton

[14] De La Mata, T., \& Llano, C. (2013). Social Networks and Trade of Services: Modelling Inter-regional Flows with Spatial and Network Autocorrelation Effects. Journal of Geographical Systems, 15(3), 319-367

[15] Deng, M., \& Athanasopoulos, G. (2011). Modelling Australian Domestic and International Inbound Travel: A Spatial-temporal Approach, Tourism Management, 32, 1075-1084

[16] DiPietro, R. B., Breitner, D., Rompf, P., \& Godlewska, M. (2008). An exploratory study of differences among meeting and exhibition planners in their destination selection criteria. Journal of Convention \& Event Tourism, 9(4), 258-276

[17] Dragičević, V., Jovičević, D., Belšić, I., Stankov, U., \& Bošković, D. (2012). Business tourism destination competitiveness: A case of Vojvodina Province (Serbia). Economic Research Ekonomska Istraživanja, 25(2), 311-332

[18] Draper, J., Dawson, M., \& Casey, E. (2011). An exploratory study of the importance of sustainable practices in the meeting and 
convention site selection process. Journal of Convention and Event Tourism, 12(3), 153-178

[19] Dwyer, L., Forsyth, P., \& Rao, P. (2000). The Price competitiveness of travel and tourism: A comparison of 19 destinations. Tourism Management, 21, 9-22

[20] Eilat, Y., \& Einav, L. (2004). Determinants of international tourism: A three - dimensional panel data analysis. Applied Economics, 36(12), 1315-1327

[21] Enright, M., \& Newton, J. (2004). Tourism destination competitiveness: A quantitative approach. Tourism Management, 25(6), 777-788

[22] Enright, M., \& Newton, J. (2005). Determinants of tourism destination competitiveness in Asia Pacific: Comprehensiveness and universality. Journal of Travel and Research, 43(4), 339-350

[23] Ermen, D., Gnoth, J., \& Harris, P. (2006). Tourism destination and reputation management: Towards a model of stakeholder communication. Paper Presented at the 22nd IMP Annual Conference, 7-9 September, Milan, Italy

[24] ESRI (1999). ArcView GIS 3.2. USA: Environmental Systems Research Institute Inc.

[25] Fenich, G., Scott-Halsell, S., Ogbeide, G.-C., \& Hashimoto, K. (2014). What the Millennial Generation from Around the World Prefers in Their Meetings, Conventions and Events. Journal of Conventions and Event Tourism, 15, 236-241.

[26] Flagestad, A., \& Hope, C. A. (2001). Strategic success in winter sports destinations: a sustainable value creation perspective, Tourism Management, 22, 445-461

[27] Guizzardi, A. (2005). A new approach in business travel survey: multivariate techniques for strata design. In M. Vichi, P. Monari, S. Mignani, \& A. Montanari (eds.), New developments in classification and data analysis (pp. 311-316). Heidelberg: Springer

[28] Hankinson, G. (2005). Destination brand images: A business tourism perspective. Journal of Services Marketing. 19(1), 24-32

[29] Haven-Tang, C., Jones, E., \& Webb, C. (2007). Critical success factors for business tourism destination. Journal of Travel \& Tourism Marketing, 22(3/4), 109-120

[30] Hong, L., \& Yan, J. (2011). Construction the tourism supply chain focusing on the tourism destination as the core. Paper Presented at International Conference on E-Business and EGovernment (ICEE), 6-8 May, Shanghai, China

[31] Judith, M., \& Thompson, K. (2009). The UK association conference attendance decision-making process. Tourism Management, 30(3), 400-409

[32] Kaufmann, D., Kraay, A., \& Mastruzzi, M. (2008). Governance matters VII: governance indicators for 1996-2007. World Bank Policy Research

[33] Kaukal, M., Höpken, W., \& Werthner, H. (2000). An Approach to Enable Interoperability in Electronic Tourism Markets. Paper Presented at the Proceedings of the 8th European Conference on Information System (ECIS 2000), 3-5 July, Wienna, Austria

[34] Kellerman, A. (2010). Business travel and leisure tourism: comparative trends in a globalizing world. In J. Beaverstock, B. Deruder, J. R. Faulconbridge \& F. Witlox (eds.), International business travel in the global economy (pp. 165-175). Surrey: Ashgate
[35] Kulendran, N., \& Witt, S. (2003). Forecasting the demand for international business tourism. Journal of Travel Research. 41(3), 265-271

[36] Lee, T. H., \& Park, J.-Y. (2002). Study on the degree of importance of convention service factors: Focusing on the differences in perception between convention planners and participants. Journal of Convention \& Exhibition Management, 3(4), 69-85

[37] Lloyd, P.J., \& MacLaren, D. (2002). Measures of trade openness using CGE analysis. Journal of Policy Modeling, 24, 67-81

[38] Manski, C.F. (2000). Economic analysis of social interactions. Journal of Economic Perspectives, 14(3), 115-136

[39] Marrocu, E., \& Paci, R. (2011). They Arrive with New Information. Tourism Flows and Production Efficiency in the European Regions. Tourism Management, 32, 750-758

[40] Marrocu, E., \& Paci, R. (2013). Different Tourists to Different Destinations. Evidence from Spatial Interaction Models. Tourism Management, 39, 71-83

[41] Middleton, V., Fyall, A., Morgan, M., \& Ranchhod, A. (2009). Marketing in Travel and Tourism (4th ed.). Burlington: Butterworth-Heinemann

[42] Mill, R. C. (2010). Tourism the International Business. Zurich: Jacobs Foundation

[43] Muñoz, T. G., \& Martin, L. F. M. (2007). Tourism in the Balearic Islands: a dynamic model for international demand using panel data. Tourism Management, 28(5), 1224-1235

[44] Murphy, P., Pritchard, M. P., \& Smith, B. (2000). The destination product and its impact on traveller perceptions. Tourism Management, 21(1), 43-52

[45] Oppermann, M. (1996). Convention destination images: analysis of association meeting planners' perceptions. Tourism Management, 17(3), 175-182

[46] Oppermann, M., \& Chon, K.-S. (1997). Convention participation decision-making process. Annals of Tourism Research, 24(1), 178-191

[47] Paci, R., \& Marrocu, E. (2014). Tourism and regional growth in Europe. Papers in Regional Science, 93(Supplement 1), S25S50

[48] Page, S. J. (2003). Tourism Management - Managing for Change. Oxford: Butterworth Heinemann

[49] Park, J., Wu, B., Shen, Y., Morrison, A., \& Kong, Y. (2014). The Great Halls of China? Meeting Planners' Perceptions of Beijing as an International Convention Destination. Journal of Convention \& Event Tourism, 15, 244-270.

[50] Pavlovich, K. (2003). The Evolution and Transformation of a Tourism Destination Network: The Waitomo Caves, New Zealand. Tourism Management, 24(2), 203-216

[51] Pike, S. (2008). Destination Marketing - An Integrated Marketing Communication Approach. New York: Routledge

[52] Seetaram, N. (2012). Immigration and international inbound tourism: Empirical evidence from Australia. Tourism Management, 33, 1535-1543

[53] Severt, D., Wang, Y., Chen, P., \& Breiter, D. (2007). Examining the motivation, perceived performance and behavioral intentions of conventions attendees: Evidence from a regional conference. Tourism Management, 28, 399-408

[54] Shin, Y. (2009). Examining the link between visitors' motivations and convention destination image, Tourismos: An International Multidisciplinary Journal of Tourism, 4(2), 29-45 
[55] Smith, S. L. J. (1988). Defining Tourism: A Supply-Side View. Annals of Tourism Research, 15(2), 179-190

[56] Sox, C. B., Benjamin, S., Carpenter, J., \& Strick, S. (2013). An exploratory study of meeting planner and conference attendees' perceptions of sustainable issues in convention centers. Journal of Convention and Event Tourism, 14(2), 144-161

[57] Tapper, R., \& Font, X. (2004). Tourism Supply Chains: Report of a Desk Research Project for The Travel Foundation. Retrieved 15.02.2012, from International Centre for Responsible Tourism. Available at: http://icrtourism.com.au/wp-content/ uploads/2012/09/TourismSupplyChains.pdf

[58] Var, T., Cesario, F., \& Mauser, G. (1985). Convention tourism modelling. Tourism Management, 6(3), 195-204

[59] Whitfield, J., Dioko, L., Webber, D., \& Zhang, L. (2014). Attracting Convention and Exhibition Attendance to Complex MICE Venues: Emerging Data from Macao. International Journal of Tourism Research, 16, 169 - 179.

[60] Wootton, G., \& Stevens, T. (1995). Business tourism: a study of the market for hotel-based meetings and its contribution to Wales's tourism. Tourism Management. 16(4), 305-313

[61] World Travel \& Tourism Council (2011). Travel \& Tourism Economic Impact 2011 - World. London: Author

[62] Yoo, J. J., \& Zhao, X. (2010). Revisiting determinants of convention participation decision making. Journal of Travel \& Tourism Marketing, 27(2), 179-192.

[63] Zhang, H. Q., Leung, V., \& Qu, H. (2007). A refined model of factors affecting convention participation decision-making. Tourism Management, 28(4), 1123-1127

[64] Zhang, X., Song, H., \& Huang, G. Q. (2009). Tourism supply chain management: A new research agenda. Tourism Management, 30(3), 345-358

[65] Zhang, Y., Xu, J.-H., \& Zhuang, P.-J. (2011). The Spatial Relationship of Tourist Distribution in Chinese Cities. Tourism Geographies, 13(1), 75-90

PEDRO CARVALHO (PhD) is an Adjunct Professor in the School of Technology and Management at the Polytechnic Institute of Viana do Castelo (Portugal). He received his $\mathrm{PhD}$ from the Extremadura University in Spain (2014), MS from the Portucalense University Infante D. Henrique (2004) and BS from the Lusophone University of
Humanities and Technologies in Portugal (1999). Pedro's research is concerned with business tourism and relationship marketing. Currently, he teaches both undergraduate and graduate students in the areas of marketing. Address: School of Technology and Management, Polytechnic Institute of Viana do Castelo, Avenida do Atlântico, 4900348 Viana do Castelo, Portugal.

MIGUEL A. MÁRQUEZ(PhD) is the Head of the Department of Economics at the University of Extremadura (Spain) and Scientific Secretary of the Spanish Association of Regional Science (AECR). He is an Affiliate Research Professor at the Regional Economics Applications Laboratory (University of Illinois, USA). His major research work has covered a variety of topics related to both the field of regional economics and the field of economic growth, with a special focus on the design, implementation and application of economic models. He has published a number of papers in major journals (such as European Economic Review, Environment and Planning A, and Papers in Regional Science), participating in many different competitive research projects. Address: Department of Economics, University of Extremadura, Avda. de Elvas, 06071 Badajoz, Spain

MONTSERRAT DÍAZ MÉNDEZ (PhD) has a degree in Administration and Business Management from the University of Extremadura and $\mathrm{PhD}$ in Business Administration from the University of Navarra. She is currently a Professor of Communication and Ethics in the Faculty of Economics and Business Administration at the University of Extremadura. She conducted research at the University of Stockholm (Sweden) with the Professor Evert Gummesson and Professor Michael Saren at the University of Leicester (UK). Address: Department of Management, University of Extremadura, Avda. de Elvas, 06071 Badajoz, Spain 


\section{Appendix}

List of countries in the sample: Antigua and Barbuda, Algeria, Azerbaijan, Albania, Armenia, Angola, Argentina, Austria, Barbados, Botswana, Belgium, Bahamas, Bangladesh, Bosnia and Herzegovina, Bolivia, Benin, Belarus, Brazil, Bulgaria, Canada, Cambodia, Chad, Sri Lanka, Congo, China, Chile, Cameroon, Colombia, Costa Rica, Central African Republic, Cape Verde, Cyprus, Denmark, Dominican Republic, Ecuador, Egypt, Ireland, Estonia, El Salvador, Ethiopia, Czech Republic, Finland, Fiji, France, Gambia, Gabon, Ghana, Grenada, Germany, Greece, Guatemala, Guinea, Honduras, Croatia, Hungary, Iceland, Indonesia, India, Israel, Italy, Japan, Jamaica, Jordan, Kenya, Kyrgyzstan, South Korea, Kazakhstan, Laos, Lebanon, Latvia, Lithuania, Lesotho, Luxembourg, Madagascar, Macau, Moldova, Mongolia, Malawi, Macedonia, Morocco, Mauritius, Malta, Oman, Maldives, Mexico, Malaysia, Mozambique, Vanuatu, Nigeria, Netherlands, Norway, Nepal, Nicaragua, New Zealand, Paraguay, Peru, Pakistan, Poland, Panama, Portugal, Papua New Guinea, Qatar, Romania, Philippines, Russia, Rwanda, Saudi Arabia, St. Kitts and Nevis, Seychelles, South Africa, Senegal, Slovenia, Sierra Leone, Spain, Serbia, St. Lucia, Sudan, Sweden, Syria, Switzerland, United Arab Emirates, Thailand, Tunisia, Turkey, Tanzania, United Republic of Uganda, United Kingdom, Ukraine, United States, Uruguay, St. Vincent and the Grenadines, Venezuela, Vietnam, Namibia, Swaziland, Zambia. 